\title{
The analysis of the implementation of the environmental impact assessment of projects in the Polish legal system
}

\author{
Analiza przebiegu implementacji \\ postępowania w sprawie oceny \\ oddziaływania przedsięwzięć na środowisko \\ w polskim porządku prawnym
}

\begin{abstract}
The European Union requires an environmental impact assessment to be carried out before approval can be granted for certain public and private projects. Due to the fact that it is regulated at the level of the European Union law, Member States are responsible for the implementation of those regulations. In this article the author conducts an assessment of the course of implementation of the EU Directives regulating the proceeding concerning the environmental impact assessment in the
\end{abstract}

- Ph.D. Candidate at Faculty of Law and Administration, University of Warsaw. 


\section{Magdalena Brodawka}

Polish legal system by indicating the issues and challenges connected with ensuring their proper implementation. The problem is particularly valid, especially in the light of the recent changes in the EU regulations which concern this proceeding.

Key words: Environment; environmental impact assessment; European Union law; implementation

\section{Streszczenie}

Unia Europejska wymaga przeprowadzenia postępowania w sprawie oceny oddziaływania przedsięwzięć na środowisko przed wydaniem zgody na realizację określonych inwestycji. Z uwagi na fakt, że procedura ta ustanowiona jest na poziomie prawa Unii Europejskiej, państwa członkowskie są zobowiązane do implementacji odpowiednich regulacji. W niniejszym artykule autor dokona oceny przebiegu procesu wdrażania dyrektyw unijnych z zakresu ocen oddziaływania przedsięwzięć na środowisko w polskim porządku prawnym, poprzez określenie trudności i wyzwań związanych z zapewnieniem odpowiedniej transpozycji tych regulacji. Wskazany problem jest szczególnie aktualny, zwłaszcza w świetle ostatnich zmian prawa Unii Europejskiej w zakresie dotyczącym omawianej procedury.

Słowa kluczowe: Środowisko; ocena oddziaływania na środowisko; prawo Unii Europejskiej; implementacja

\section{Introduction}

Currently, almost every activity undertaken by a man has an impact on the environment, which applies particularly to the investment and construction processes. This is the reason why the measures and methods which are preventive and precautionary in nature, and which are aimed at managing the investment activity of a man in order to prevent the occurrence of the negative impact on the environment as soon as possible, are especially significant for the environmental protection $\mathrm{law}^{1}$. The instrument which is employed to execute the aforementioned tasks is the environmental

1 P. Grabowski, Ocena regulacji prawnej w kontekście zasady przezorności i prewencji, Prawo i Środowisko 2011, No 4, p. 115. 
impact assessment of projects, which is currently perceived as one of the basic means of preventive environmental policy ${ }^{2}$. The literature mentions that the core of such a proceeding is to make an assessment as to how the planned project will impact the environment ${ }^{3}$, and, as a result, to "optimize the process of making the decision permitting the execution of a particular project" 4

It should be emphasized that the discussed mechanism is a subject to regulation in accordance with the European Union law, which is connected with the obligation of the Polish legislator to ensure the full implementation of that regulation in the national legal system. The experience shows that the need to ensure the compliance of the national law with the requirements of the European Union law can frequently give a rise to significant difficulties. In this article the author conducts an assessment of the course of the implementation of the EU Directives regulating the proceeding concerning the environmental impact assessment in the Polish legal system by indicating the issues and challenges connected with ensuring their proper implementation. The problem is particularly valid, especially in the light of recent changes in the EU regulations which concern this proceeding.

\section{The provisions of the European Union law in the scope of the environmental impact assessment of projects}

Firstly, it should be noted that the need to regulate the proceeding concerning the environmental impact assessment of projects at the level of the European Union law was acknowledged relatively early, since it was considered

2 M. Pchałek, M. Behnke, Postepowanie w sprawie oceny oddziatywania na środowisko w prawie polskim i UE, Warszawa 2009, p. 3.

3 B. Rakoczy, Ustawa o udostępnianiu informacji o środowisku i jego ochronie, udziale spoteczeństwa w ochronie środowiska oraz o ocenach oddziatywania na środowisko. Komentarz, Warszawa 2010,p. 163.

4 B. Winiszewska, J.A. Farr, J.Jendrośka, Postępowanie w sprawie oceny oddziatywania na środowisko planowanych przedsięwzięć, Warszawa 2002, p. 12. 
in programs regarding environmental activities from $1973^{5}, 1977^{6}$ and $1983^{7}$. All three programs indicated that an optimal environmental protection policy consisted in preventing pollution and damage to the environment rather than combating their outcome afterwards. Considering the above, the Directive 85/337/EEC on the assessment of the effects of certain public and private projects on the environment ${ }^{8}$ was adopted and it established detailed principles for the assessment of the impact on the environment resulting from some public and private projects, in order to coordinate procedures concerning issuing permits for those projects ${ }^{9}$.

Over the years the changes in the approach of the European Union to issues connected with the environmental protection caused the Directive to be a subject to numerous major amendments. In 1997 the Directive $85 / 337 /$ EEC was amended by the Directive $97 / 11 / E^{10}$. It should be noted that the alteration introduced by the aforementioned Directive is considered to be the most significant of all the previous amendments ${ }^{11}$. The objective of the alteration was, for instance, putting the incomplete regulation concerning the application of provisions concerning conducting a proceeding regarding the environmental impact assessment in order by

5 Declaration of the Council of the European Communities and of the representatives of the Governments of the Member States meeting in the Council on the programme of action of the European Communities on the environment, C 112, p. 1.

6 Declaration of the Council of the European Communities and of the representatives of the Governments of the Member States meeting in the Council on the continuation of the implementation of a European Community policy and action programme on the Environment, C 139, p. 1.

7 Declaration of the Council of the European Communities and of the representatives of the Governments of the Member States meeting in the on the continuation and implementation of a European Community policy and action programme on the Environment (1982-1987), C 46, p. 1.

8 Council Directive 85/337/EEC of 27 June 1985 on the assessment of the effects of certain public and private projects on the environment, OJ L 175, 5.7.1985, p. 40-48.

9 Pchałek M. and Behnke, M. Postępowanie... op. cit, p. 13.

10 Council Directive 97/11/EC of 3 March 1997 amending Directive 85/337/EEC on the assessment of the effects of certain public and private projects on the environment OJ L 73, 14.3.1997, p. 5-15.

11 Dyrektywa 2011/92/UE w sprawie oceny oddziatywania na środowisko. Opracowanie, ed. Z. Bukowski, lexis/el. 
including the acquis of judicial decisions on the subject made by the Court of Justice of the European Union ${ }^{12}$.

Significant changes in the subject of the Directive 85/337/WE regulation were introduced by the Directive $2003 / 35 / \mathrm{EC}^{13}$. The indicated alteration aimed at adjusting the content of the Directive 85/337/EEC to the requirements set forth in the Aarhus Convention ${ }^{14}$. It should be emphasized that the aforementioned Convention plays an important role from the perspective of the environmental impact assessment of projects. This is because it regulates the issue of the participation of the public in decision making processes connected with the environment by determining the standards for the participation of the public in the decision making processes concerning particular types of activity. Thus, it aims to ensure the transparency of the decision making, and its objective is to strengthen the support of the society for decisions concerning the environment, such as permits for the execution of particular projects, which may have an impact on the environment.

Another change in the field of the environmental impact assessment of projects took place in 2009 and was introduced by the Directive $2009 / 31 / \mathrm{EC}^{15}$. The new regulation expanded the scope of projects which required the environmental impact assessment to be made, by including projects connected with transport and carbon capture and storage, which is considered as an immense progress of the European Union regarding

12 W.R. Sheate, The Environmental Impact Assessment Amendment Directive 97/11/EC - A Small Step Forward? European Energy and Environmental Law Review 1997, No 6, p. 235.

13 Directive 2003/35/EC of the European Parliament and of the Council of 26 May 2003 providing for public participation in respect of the drawing up of certain plans and programmes relating to the environment and amending with regard to public participation and access to justice Council Directives 85/337/EEC and 96/61/EC, OJ L 156, 25.6.2003, p. $17-25$.

14 Convention on Access to Information, Public Participation in Decision-making and Access to Justice in Environmental Matters, Aarhus 1998.

15 Directive 2009/31/EC of the European Parliament and of the Council of 23 April 23 2009 on the geological storage of carbon dioxide and amending Council Directive 85/337/ EEC, European Parliament and Council Directives 2000/60/EC, 2001/80/EC, 2004/35/ EC, 2006/12/EC, 2008/1/EC and Regulation (EC) No 1013/2006 OJ L 140, 5.6.2009, p. $114-135$ 


\section{Magdalena Brodawka}

the creation of a legal framework for processes connected with carbon storage $^{16}$.

As a result of the changes mentioned above, to which the Directive $85 / 337 /$ EEC was subjected, it became necessary to unify it in order to retain its transparency and the comprehensibility of its contents. Another aim of the amendments was to simplify the form of the Directive by making it more understandable from the legal point of view, which was meant to facilitate the process of its implementation. Due to that the Directive 85/337/EEC, together with the three aforementioned European Union laws amending it, was unified with the Directive 2011/92/EU ${ }^{17}$.

It is worth noting that regardless of the indicated amendment of the Directive, the European Commission did not cease activities aimed at adjusting those regulations to the current conditions. In July 2009 a report of the European Commission regarding the application and the effectiveness of the Directive $85 / 337 /$ EEC was published ${ }^{18}$. In the report the European Commission indicated the beneficial factors of the Directive while emphasizing the main issues which required improving, and in relevant cases appropriate recommendations and ways to improve those regulations were set forth. It is important that the European Commission emphasized that the development of the environmental impact assessments was a continuous process. Hence, the adjustment of the Directive to the EU and international political and legal conditions must be ensured ${ }^{19}$.

Due to that in June 2010 the Commission launched a public consultation concerning a wide range of topics, such as the quality of the proceedings concerning the environmental impact assessment, unifying the requirements for the assessment of the environmental impact among Member States or the role of state authorities in the execution of the procedure. The results of the public consultation were presented at a conference organized by

16 F. Junge, Carbon Capture and Storage and international maritime agreements. Current state, progress and challenges, Groningen 2011, p. 1.

17 Directive 2011/92/EU of the European Parliament and of the Council of 13 December 2011 on the assessment of the effects of certain public and private projects on the environment, OJ L 26, 28.1.2012, p. 1-21.

18 Report from the Commission to the Council, the European Parliament, the European Economic and Social Committee and the Committee of the Regions on the application and effectiveness of the EIA Directive (Directive 85/337/EEC, as amended by Directives 97/11/ EC and 2003/35/EC). COM(2009) 378.

19 Ibidem, p. 10 
The analysis of the implementation of the environmental impact assessment...

the European Commission on 18-19 November 2010 in Leuven under the name: "25th Anniversary of the EIA Directive: Successes - Failures Prospects" 20 . It should be emphasized that both the results of the conducted consultation, as well as the conclusions presented during the conference had an important influence on the revision of the Directive's provisions.

The result was adoption of the proposal of the European Commission in October 2010 concerning the Directive of the European Parliament and of the Council on the assessment of the effects of certain public and private projects on the environment ${ }^{21}$. It should be emphasized that the Commission indicated a range of fundamental changes, which would aime at, for instance, increasing the quality of the procedure of the environmental impact assessments and ensuring the coherence and coordination with regard to the requirements stipulated in other EU regulations ${ }^{22}$.

The activities undertaken by the Commission were concluded with the adoption of the Directive 2014/52/EU amending the Directive 2011/92/EU on 16 April 2014 ${ }^{23}$. The amendment was meant to ensure better protection of the environment, more efficient management of resources, and the support of sustainable growth in the European Union. Due to that, a range of important amendments has been introduced as a part of procedures connected with the execution of the environmental impact assessments of projects. The most important of those modifications include, for instance, defining the term "environmental impact assessment" (making the definition of individual stages of the proceeding more precise), introducing new requirements concerning the report on the environmental impact assessment (the need for the proceeding to be conducted by accredited experts) or extending the stage of public consultation (increasing the significance of the community's involvement in the proceeding).

Member States must implement new EU regulations by 16 May 2017 at the latest, i.e. within three years from the day the Directive 2014/52/EU came into force. The need to implement those regulations is connected with

20 Source: <http://ec.europa.eu/environment/eia/conference_25years.htm> (14.11.2014).

21 Proposal for a Directive of the European Parliament and of the Council amending Directive 2011/92/EU on the assessment of the effects of certain public and private projects on the environment. $\mathrm{COM}(2012) 628$.

22 Ibidem, p. 4.

23 Directive 2014/52/EU of the European Parliament and of the Council of 16 April 2014 amending Directive 2011/92/EU on the assessment of the effects of certain public and private projects on the environment, OJ L 124, 25.4.2014, p. 1-18. 
important obligations on the part of Member States, which requires a more detailed presentation.

\section{The significance and nature of the implementation in the European Union law}

Due to the fact that a proceeding on the environmental impact assessment of projects is a subject to the regulations of the Directives, it is crucial to discuss the matters related to the process of implementation of those European Union laws in greater detail. First, it should be emphasized that, pursuant to article 288 of the Treaty on the Functioning of the European Union ${ }^{24}$ "A Directive shall be binding, as to the result to be achieved, upon each Member State to which it is addressed, but shall leave to the national authorities the choice of form and methods". According to this provision, a Directive is binding as to the result, while Member States are free in the scope of the selection of forms and methods for the introduction of a Directive to the domestic legal system ${ }^{25}$.

The implementation is the process which consists in achieving the result indicated by the Directive, and which Member States are obliged to achieve. This is a complex mechanism which involves the transposition, which is also called the transfer, due to the process of transferring the EU norms to national legal systems and their application, as well as the employment of the EU legal norms ${ }^{26}$. Thus, the implementation of the European Union law consists of three elements, each of which is a subject to the EU's control, and is connected with the country being responsible for it and, in the case of any irregularities, there is also the possibility of imposing penalties ${ }^{27}$. It should be noted that sometimes the terms - implementation and transposition - are used interchangeably in the literature ${ }^{28}$. At the same

24 Treaty on the Functioning of the European Union, OJ C 326, 26.10.2012, p. 47-390.

25 A. Zawidzka, Prawo pochodne Unii Europejskiej. in: Źródta prawa Unii Europejskiej, ed. J. Barcz, Warszawa 2010, p. 27.

26 M.M. Kenig-Witkowska, Prawo środowiska Unii Europejskiej. Zagadnienia systemowe, Warszawa 2011, p. 168.

27 Z. Bukowski, Prawo ochrony środowiska Unii Europejskiej, Warszawa 2007, p. 278.

28 A. Zawidzka, Prawo... op. cit., p. 29. 
The analysis of the implementation of the environmental impact assessment...

time, it should be emphasized that despite the fact that the scope in which a Directive is binding is the smallest, when compared to that of a Regulation or a Decision ${ }^{29}$, it is not binding at a lower degree than other derived laws, and the objective which is to be achieved is frequently stated in a very precise and detailed manner ${ }^{30}$.

It is important that the implementation of Directives cannot be merely conducted in any random way, since it must comply with the principles which are set forth by the Court of Justice in its extensive case law. This is particularly vital in order to ensure the effectiveness of the European Union law, as without a proper implementation the EU law could not be efficiently employed and followed ${ }^{31}$. Due to the aforementioned, it is suggested that the implementation of the European Union law is a subject to the efficiency principle, which means that the planned result must be properly achieved in order to create appropriate conditions for the efficient application and observance of the European Union legal norms ${ }^{32}$. Also, it should be noted that the implementation of Directives is a subject to the principle of equivalence, which means that Member States must use such local methods and measures which enable the execution of Directives' contents and the observance of their provisions ${ }^{33}$.

The Court of Justice has spoken about the obligation to implement Directives on numerous occasions. In the judicial decision dated on 10 April 1984, case file C-14/83, von Colson and Kamann vs Land NordrheinWestfalen ${ }^{34}$, the court indicated that Member States were obliged to take all necessary steps to ensure that a Directive was fully efficient and compliant with the objective at which it aimed. The Court of Justice has supplemented those remarks in another judicial decision ${ }^{35}$ by indicating

29 J. Maliszewska-Nienartowicz, System instytucjonalny i prawny Unii Europejskiej, Toruń 2010, p. 278.

30 A. Zawidzka, Prawo... op. cit., p. 28.

31 M. Szwarc, Warunki poprawnej implementacji dyrektyw porzadkach prawnych pañstw cztonkowskich w świetle prawa wspólnotowego, Przegląd Prawa Europejskiego 2001, No 9 , p. 6.

32 C. Mik, Europejskie prawo wspólnotowe. Zagadnienia teorii i praktyki, Warszawa 2000, p. 659.

33 Ibidem, p. 662.

34 Case C-14/83 Sabine von Colson and Elisabeth Kamann v. Land NordrheinWestfalen, ECR 1984, p. I-1891.

35 Joined Cases C-178/94, C-179/94, 188/94, 189/94, 190/94 Erich Dillenkofer and Others v. Germany, ECR 1996, p. I-4845. 


\section{Magdalena Brodawka}

that the provisions of a Directive must be implemented in such a way as to give them an unquestionable binding force. Therefore, issuing standard circulars, for instance, cannot be perceived as taking proper steps regarding the implementation, because they could be altered by administrative bodies at any time ${ }^{36}$.

Moreover, the very existence of the practice which is compliant with the provisions of a Directive also does not constitute a condition relieving the state from the obligation to transpose it to the state legal system, because such a practice can be altered at any time as well ${ }^{37}$. This suggests that the obligation to execute the transposition could only be fulfilled by issuing commonly binding laws, such as an act or an ordinance. The Court of Justice has also noted that the contents of norms transposing a Directive should be transparent and clear, particularly when the aim of a Directive is to ensure certain rights of individuals ${ }^{38}$. It is important that the implementation does not need to constitute a word-for-word repetition of the provisions of a Directive in a national law ${ }^{39}$. However, it is not permitted to adopt by the state only a partial regulation ${ }^{40}$.

While discussing the process of implementing the European Union law from the perspective of the environmental impact assessments, the specific nature of the environmental law norms, which significantly influence the implementation process, should be kept in mind. The literature suggests that "the implementation of the law on the environmental protection is particularly problematic in every legal system" ${ }^{\prime 1}$. This is because specific features of such law must be considered, including the technical nature of legal norms in that scope ${ }^{42}$. Due to that fact, Member States have not only legal obligations imposed on them, which result from the provisions of Directives, but also a range of obligations which are material in nature and relate to monitoring the employment of the required standards, e.g. regarding

36 Case C-239/85 Commission v. Belgium, ECR 1986, p. I-3657; Case C-316/96 Commission v. Italy, ECR 1997, p. I-7231.

37 Case C-29/84 Commission v. Germany, ECR 1985, p. I-1661.

38 Case C-144/99 Commission v. Netherlands, ECR 2001, p. I-3541.

39 Case C-247/85 Commission v. Belgium, ECR 1987, p. I-3090.

40 Case C-298/97 Commission v. Spain, ECR 1998, p. I-3301.

41 L. Kramer, Implementation of the environment al acquis in the Member States, in: Environmental acquis and its implementation in Poland three years after accession, ed. L. Kramer, Wrocław 2008, p. 13.

42 M.M. Kenig- Witkowska, Prawo... op. cit., p. 170. 
the quality of water and $\operatorname{air}^{43}$. It should be emphasized, that in order to ensure the fulfillment of those requirements, material requirements should be analyzed not only from the point of view of methods, manners and forms of the implementation, but also their results.

The subsequent feature characteristic for the European Union law on the environmental protection, which should be considered and analyzed during the implementation, is the practically unlimited circle of persons to whom rights are granted ${ }^{44}$. This is connected with the fact that the provisions of a Directive protect the rights of all persons who may be exposed to the risks connected to it e.g. with the low quality of water or air, and, at the same time, they create an obligation on the part of specified entities who are responsible for causing pollution or degradation of the environment.

Pursuant to the aforementioned, in the case of a transposition of the European Union law on the environment it is particularly important for the contents of the norms transposing a Directive to be clear and transparent due to the fact that, in principle, the subject of a Directives on the environmental protection is ensuring particular rights of individuals ${ }^{45}$. The Court of Justice has pointed out that Directives setting standards of quality ${ }^{46}$ grant specific rights of individuals and thus, those Directives, in particular, should be transposed to the national legal system through legally binding instruments.

The aforementioned remarks confirm that the implementation of the European Union law is a complex process which frequently causes important difficulties for Member States. This is particularly visible in the case of the regulations in the scope of the environmental law, which include provisions concerning the environmental impact assessment of projects. Moreover, the Polish legislator has also faced problems regarding the efficient implementation of those provisions on numerous occasions.

\footnotetext{
3 Ibidem.

44 Ibidem.

45 Case C-144/99 Commission v. Netherlands, ECR 2001, p. I-3541.

46 i.e. Council Directive 98/83/EC of 3 November 1998 on the quality of water intended for human consumption, OJ L 330, 5.12.1998, p. 32-54.
} 


\section{Adjusting Polish law to the requirements of the European Union}

While discussing the issue of implementing a proceeding regarding the environmental impact assessment of projects in the Polish legal system, Polish laws, which are meant to ensure the proper implementation of the EU Directives, should be indicated. They include the Act of 3 October 2008 on Access to Information on Environment and its Protection, Public Participation in Environmental Protection and on Environmental Impact Assessment ${ }^{47}$. As the title suggests, this act regulates the issues connected with the assessment of the impact which could result from the execution of particular projects, as well as the subject of instruments which aim is to guarantee the full objectiveness of the process, which also involves the access to the information on the status and the protection of the environment and the participation of the society in the process of the assessment ${ }^{48}$.

The aforementioned act is not the only national law which transposes the EU Directives in the scope of the environmental impact assessment. It should be emphasized, that such regulations were implemented in the Polish legal system along with other normative acts at the statutory and regulatory level: the provisions of the Environmental Protection Act of 27 April $2001^{49}$, the Act on Nature Conservation of 16 April 200150, as well as the Ordinance of the Council of Ministers of 9 November 2010 on projects which can significantly affect environment ${ }^{51}$.

While analyzing the issues connected with the implementation of procedures related to the environmental impact assessment a particularly great deal of attention should be devoted to the provisions of the Act on Access to Information, and the changes to which it was subjected in order to ensure a proper and full transposition of Directives. This is because the binding act has been subjected to numerous alterations since

47 Journal of Laws of 2008, No 199, item 1227 with amendments.

48 K. Gruszecki, Komentarz do ustawy z dnia 3 października 2008 r. o udostęnianiu informacji o środowisku i jego ochronie, udziale spoteczeństwa w ochronie środowiska oraz o ocenach oddziatywania na środowisko, Wrocław 2009, p. 3.

49 Journal of Laws of 2001, No 62, item 627 with amendments.

50 Journal of Laws of 2004, No 92, item 880 with amendments.

51 Journal of Laws of 2010, No 213, item 1397. 
The analysis of the implementation of the environmental impact assessment...

it was adopted in its primary wording. The literature contains suggestions that the first significant stage of the process of adjusting Polish regulations concerning the proceeding on the environmental impact assessment of projects to the requirements of the acquis communautaire of the European Union was concluded on the day when the Act of 9 November 2000 on Access to Information on Environment and its Protection was adopted ${ }^{52}$. After 5 years since the day the act came into force on 18 May 2005 the Act on the Change of the Environmental Protection Act and Certain other Acts ${ }^{53}$ was adopted. It introduced significant changes to the proceeding on the environmental impact assessment of projects. As the contents of the grounds for the project of the amending act suggested, the introduced changes aimed at ensuring the proper transposition of the European Union law. This was also shown by way of e.g. simplifying the proceeding on the environmental impact assessment by removing the requirement to conduct the proceeding for the same project several times.

Despite the fact that the assumption of the introduced regulation was to simplify the procedure of the environmental impact assessment of projects, it caused some objections on the part of the European Commission, which sent a reasoned opinion to Polish authorities, which specified in detail the so-called violation No 2006/2281. The European Commission indicated that Polish regulations concerning the procedure for obtaining a consent to execute construction investments contradicted the law of the European Union due to the lack of compliance with the term of an "investment permit" adopted in the Council's Directive 85/337/EEC. The Commission did not support the reasoning of the Polish side, which indicated that environmental decision were an equivalent of the investment permit in the Polish legal system, since they constituted a mandatory requirement for the execution of an project which might have had a significant impact on the environment ${ }^{54}$.

As a result of the guidelines set by the Commission, the Act on Access to Information on Environment and its Protection, Public Participation in Environmental Protection and on Environmental Impact Assessment was adopted on 3 October 2008. The act restored the two-stage scheme

52 Journal of Laws of 2000, No 109, item 1157.

53 Journal of Laws of 2005, No 113, item 954.

54 M. Bielecki, Decyzja o srodowiskowych uwarunkowaniach - wybrane zagadnienia, Nieruchomości 2011, No 1, p. 10. 


\section{Magdalena Brodawka}

for the environmental impact assessment and imposing the necessity to conduct an environmental impact assessment of projects as required by law.

The amendments, to which the aforementioned act was subjected, proved that the legislator tried to ensure a full and proper transposition of the EU Directives to the Polish legal system. Still, it should be noted that there may be the need to amend the provisions again as a result of the Directive 2014/52/EU in order to ensure its proper transposition.

The implementation of the proceeding on the environmental impact assessment in the Polish legal system certainly gives rise to numerous significant issues, also at the stage of the implementation of that law. The issues connected with parties to the proceeding on the environmental impact assessment, the problem of non-compliance of the project with the zoning plan the scope of the environmental impact assessment report, and issues connected with the participation of the society and the classification of projects should be indicated in particular with respect to the above ${ }^{55}$.

The determination of persons who should be considered a party to the proceeding on the environmental impact assessment is a matter which has been a subject of considerations by Polish administrative courts for many years. The Supreme Administrative Court has spoken on numerous occasions on this matter ${ }^{56}$ and has indicated that the determination of parties to the environmental impact assessment proceeding is executed pursuant to the provisions of article 28 of the Code of Administrative Proceedings of 14 June $1960^{57}$. Pursuant to that article Polish administrative courts assume that the status of a party to proceedings connected with the environmental impact assessment of projects should be attributed to entities which properties are located within the possible range of the planned project's impact. Therefore, the decisive reason for determining whether an entity has the status of a party to proceedings connected with the environmental impact assessment of projects is determining the scope of the planned project's impact ${ }^{58}$.

\footnotetext{
55 N.J. Nowak, Najważniejsze problemy prawne zwiqzane z ocenq oddziatywania przedsięwzięcia na środowisko, Nieruchomości 2013, No 2, p. 9-12.

56 Judgment of the Supreme Administrative Court of 9 December 2011, II OSK 1791/10; Judgment of the Supreme Administrative Court of 5 October 2011, II OSK 1791/10.

57 Journal of Laws of 1960, No 30, item 168 with amendments.

58 Judgment of the Supreme Administrative Court of 10 May 2012, II OSK 1063/11.
} 
The analysis of the implementation of the environmental impact assessment...

It should be remembered that a proceeding connected with the environmental impact assessment of projects is concluded with an environmental decision. The aforementioned decision should be issued after confirming the compliance of the project's location with the provisions of the zoning plan, if such a plan was adopted, unless the act stipulates certain exceptions. The courts have emphasized that the subject compliance of the project's location with the provisions of the zoning plan is the fundamental criterion for the assessment of the plans of the party applying for the environmental decision ${ }^{59}$. Furthermore, it has been emphasized that if a zoning plan does not stipulate using the land for a particular project, then the authorities are obliged to reject the application due to the lack of compliance of the project with the plan without any further examination of the actual impact of the planned project on the environment ${ }^{60}$. On the other hand, the Supreme Administrative Court indicates, that such an interpretation of provisions of the zoning plan, which would be aimed at assuming that an investment is compliant with the plan only if it is specifically and individually indicated in the zoning plan, would be an overly radical limitation ${ }^{61}$.

Also, there are significant doubts connected with the nature of the environmental impact assessment report and, consequently, the role it plays in the procedure of the environmental impact assessment. The case law by administrative courts suggests that the report is a private document of the investor but it has a specific evidentiary effect. The specific nature of the report is mainly based on the connection between the comprehensive assessment of the project and the analysis of technological and legal aspects of its functions ${ }^{62}$.

It is important to note that public administration bodies are not obliged to examine or determine the parameters of the planned project based on specialized knowledge, since their role is to assess whether the report is coherent, logical, convincing and complete, both with regard to formal and substantive requirements ${ }^{63}$. It is worth noting that the court also cannot assess the contents of the report on its own, since its assessment can only

59 Judgment of the Supreme Administrative Court of 1 August 2013, II OSK 829/11.

60 Judgment of the Supreme Administrative Court of 26 April 2013, II OSK 2628/11.

61 Judgment of the Supreme Administrative Court of 9 February 2011, II OSK 116/10.

62 Judgment of the Supreme Administrative Court of 11 July 2013, II OSK 639/13.

63 Judgment of the Supreme Administrative Court of 6 February 2013, II OSK 1862/11. 


\section{Magdalena Brodawka}

pertain to the completeness and coherence of the report, and whether it meets all statutory requirements with regard to its contents ${ }^{64}$.

It should be emphasized that one of the most important topics regarding the environmental impact assessment is to ensure that the society can participate in the procedure. The Supreme Administrative Court has pointed out that the provisions of article 28 of the Code of Administrative Proceeding should not be mistaken for or considered and equivalent for the submission of observations and the conclusions, nor demanding information during the course of the proceeding by any interested entity ${ }^{65}$.

Apart from the aforementioned problems, the issues connected with the classification of an project cause significant difficulties with regard to the proper implementation. It frequently occurs that Polish administrative bodies mistakenly classify an action, which is actually a part of the planned investment, as a separate project ${ }^{66}$. It should be emphasized that the practice of an intentional division of a planned project contradicts the assumption for the environmental impact assessment, and is referred to as salami slicing. The aforementioned method is defined as an artificial division of one project into several individual ones in order to avoid the obligation to conduct an environmental impact assessment ${ }^{67}$.

As a result of the Directive 2014/52/EU coming into force, it will be necessary to introduce relevant amendments to the provisions of the Polish law, if the current regulations do not allow for the objective of the new Directive to be achieved. However, considering the nature of those amendments, it seems that the introduction of relevant amendments by the Polish legislator is inevitable. Judging from the previous experience of the implementation of regulations concerning the environmental impact assessment of projects in the Polish legal system it should be assumed that there might be some difficulties in this case as well.

64 Judgment of the Supreme Administrative Court of 1 March 2013, II OSK 2105/11.

65 Judgment of the Supreme Administrative Court of 9 April 2013, II OSK 2396/11.

66 M.J. Nowak, Najważniejsze ... op. cit., p. 10-11.

67 K. Gruszecki, Prawnepodstawyoceny wptywu naśrodowisko oddziatywańskumulowanych, Samorząd Terytorialny 2012, No 3, p. 64. 


\section{Summary}

The proceeding concerning the environmental impact assessment is a complicated and extremely complex procedure. Due to the fact that it is regulated at the level of the European Union law, Member States are responsible for the implementation of those regulations. The nature of those provisions, which are frequently unclear and imprecise, causes numerous difficulties in their implementation, which is also shown in the case of Poland. The problem seems to be particularly valid in the light of the new Directive regulating the environmental impact assessment proceeding of projects which could require the introduction of relevant amendments to the Polish law, in order to adjust it to the EU standards. Due to the fact that Member States have the time until the half of May 2017 for the implementation of those regulations, it is particularly recommended to follow the Polish legislation in that scope very carefully.

\section{Bibliography}

Bielecki M., Decyzja o środowiskowych uwarunkowaniach - wybrane zagadnienia, Nieruchomości 2011, No 1.

Bukowski Z., Prawo ochrony środowiska Unii Europejskiej, Warszawa 2007.

Grabowski P., Ocena regulacji prawnej w kontekście zasady przezorności i prewencji, Prawo i Środowisko 2011, No 4.

Gruszecki K., Komentarz do ustawy z dnia 3 października 2008 r. o udostępnianiu informacji o środowisku i jego ochronie, udziale spoteczeństwa w ochronie środowiska oraz o ocenach oddziatywania na środowisko, Wrocław 2009.

Gruszecki K., Prawne podstawy oceny wptywu na środowisko oddziatywań skumulowanych, Samorząd Terytorialny 2012, No 3.

Junge F., Carbon Capture and Storage and international maritime agreements. Current state, progress and challenges, Groningen 2011.

Kenig-Witkowska M.M., Prawo środowiska Unii Europejskiej. Zagadnienia systemowe, Warszawa 2011.

Kramer L., Implementation of the environment al acquis in the Member States, in: Environmental acquis and its implementation in Poland three years after accession, ed. L. Kramer, Wrocław 2008. 


\section{Magdalena Brodawka}

Maliszewska-Nienartowicz J., System instytucjonalny i prawny Unii Europejskiej, Torun 2010.

Mik C., Europejskie prawo wspólnotowe. Zagadnienia teorii i praktyki, Warszawa 2000.

Nowak M.J., Najważniejsze problemy prawne zwiqzane z ocenq oddziatywania przedsięwzięcia na środowisko, Nieruchomości 2013, No 2.

Pchałek M., Behnke M., Postępowanie w sprawie oceny oddziaty wania na środowisko w prawie polskim i UE, Warszawa 2009.

Rakoczy C., Ustawa o udostępnianiu informacji o środowisku i jego ochronie, udziale spoteczeństwa w ochronie środowiska oraz o ocenach oddziatywania na środowisko. Komentarz, Warszawa 2010.

Sheate W.R., The Environmental Impact Assessment Amendment Directive 97/11/EC - A Small Step Forward?, European Energy and Environmental Law Review 1997, No 6.

Szwarc M., Warunki poprawnej implementacji dyrektyw porzadkach prawnych pañstw cztonkowskich w świetle prawa wspólnotowego, Przegląd Prawa Europejskiego 2001, No 9.

Winiszewska B., Farr J.A.,Jendrośka J., Postępowanie w sprawie oceny oddziatywania na środowisko planowanych przedsięwzięć, Warszawa 2002.

Zawidzka A., Prawo pochodne Unii Europejskiej, in: Źródta prawa Unii Europejskiej, ed. J. Barcz, Warszawa 2010.

\section{Email}

magdalena.brodawka@gmail.com 